\title{
Using DNA Barcoding to Identify the Genus Lolium
}

\section{Shenmao WU ${ }^{1}$, Liping YIN ${ }^{2}$, Zhirui $\mathrm{DENG}^{1}$, Qin $\mathrm{CHEN}^{1 *}$, Yining $\mathrm{FU}^{2}$, Huajie XUE ${ }^{2}$}

\author{
'Shanghai University, SchoolofLife Sciences, No333, Nanchen road, Shanghai, China: \\ starseeker@126.com;dengzhimi@staff.shueducn;chenqincc@staff.shu.edu.cn("correspondingauthor) \\ ${ }^{2}$ Shanghai Entry-Exit Inspection and Quarantine Bureau, Technical Centerfor Animal, Plant and Food Inspection and Quarantine, No 1208, Minshengroad, Shanghai, China; \\ yinlp@shciqgovv.cn;fuyn@shciq.gov.cn;xuehj@shciq.gov.cn
}

\begin{abstract}
Seeds of the genus Lolium are difficult to identify based on morphology for morphological likeness and some physical deformation such as friction and flattening during storage and transport. DNA barcoding, a newly-established method, has been used to discriminate a variety of agricultural crops with its own advantages. In present study, DNA barcodes for the genus Lolium were investigated for the first time. DNA sequences of $p s b A-\operatorname{trn} H, r b c L$, atpF-atpH, and the ITS2 region were evaluated for their ability to differentiate Lolium from the related genus Festuca. As confirmed by inter-intraspecific divergence and Kimura 2 parameter analysis, the greatest divergence existed in ITS2, followed by psbA-trnH. On the contrary, $r b c L$ and atpF-atpH possessed poor genetic variation of 0-0.0115, and was relatively difficult in discrimination of genus Lolium. For ITS2 sequence, no inter-intraspecific distance overlaps were observed and each species has a distinct barcoding gap. ITS2 could effectively discriminate all species based on a neighbor-joining tree. Thus, the ITS2 region is a candidate for DNA barcoding of Lolium.
\end{abstract}

Keywords: atpF-atpH, DNA barcodes, Festuca, ITS2, Lolium, psbA-trnH, rbcl

\section{Introduction}

Lolium, a genus of Poaceae, consists of six species and one variety: Lolium perenne, L. persicum, L. remotum, L.multiflorum, $L$. rigidum, $L$. temulentum, and $L$. temulentum var. arvense (Raven and Zhang, 2013). Lolium perenne and L. multiflorum are widely used as cool-season forage and have high economic value. However, $L$. temulentum, when infected by fungus, can produce the toxic alkaloid temulin, which can poison livestock and humans, occasionally resulting in death (Hurst, 1942). Lolium temulentum and its variety are morphologically similar to $L$. perenne, $L$. multiflorum, and $L$. rigidum and cannot be distinguished routinely. In addition, the genus Festuca is closely related to Lolium, and their gene structures indicate they shared a common ancestor about 2.8 million years ago (Charmet et al., 1997; Torrecilla and Catalan, 2002).

Traditional taxonomy mainly relies on morphology, including seed shape, size, and other characteristics. But seed morphology is severely damaged during import, export, and transport processes. Accordingly, an accurate, sensitive, and simple alternative method is urgently needed to practically differentiate these species (Liu et al., 2012; Hebert et al., 2003).

The term "DNA barcode" for global species identification was first proposed by Hebert $e$ al. (2003). Compared with the conventional morphology, DNA barcodes are not affected by the part of the plant tested and individual developmental stages. The key to identification is to find an appropriate DNA barcode. In recent years, $r b c L$, atpF-atpH, $p s b A$-trn $H$, and ITS2 have been commonly used as DNA barcodes for plants (CBOL Plant Working Group, 2009; Chen et al., 2010).

The DNA barcodes $r b c L$ and atpF-atp $H$ are universal and easy to amplify in plants, and are widely used for phylogenetic reconstructions at the genus levels. The $p s b A$-trnH region has several advantages, including easy amplification across a broad range of land plants, conserved coding regions that simplify design, and high variability owing to the presence of huge insertions or deletions (Bhargava and Sharma, 2013).The use of the ITS2 region in phylogenetic studies has increased in recent years, so a large number of ITS2 sequence data for Poaceae are available in GenBank. It's neighboring regions, $5.8 \mathrm{~S}$ and $26 \mathrm{~S}$ rDNA, are conserved and can be used for designing primers (Gao et al., 2010; Selvaraj et al., 2012; Kitthawee et al., 2013). 
The objective of this study was to evaluate four potential DNA barcodes suggested by the CBOL Plant Working Group (2009) and other authors (Kress et al., 2005; Lahaye et al., 2008a) and applied them to Lolium and Festuca species for phylogenetic reconstructions.

\section{Materials and Methods}

\section{Plantmaterials}

Lolium, Festuca, and Cynodon samples were collected from America, Canada, and China in 2012 (Table 1). The

Table 1. Plant materials and sources

\begin{tabular}{|c|c|c|c|}
\hline No & Species & Location & Latitude/longitude \\
\hline WLM1 & L. multiflorum & America, Oregon & N42.6/E-124.1 \\
\hline WLM2 & L. multiflorum & America, Arizona & N34.1/E-110.7 \\
\hline WLM3 & L. multiflorum & France & - \\
\hline WLM4 & L. multiflorum & France & - \\
\hline WLM5 & L. multiflorum & France & - \\
\hline WLP1 & L.perenne & Canada, Manitoba & N49.6/E-95.6 \\
\hline WLP2 & L. perenne & Canada, Ontario & N49.7/E-94.3 \\
\hline WLP3 & L.perenne & America, Oregon & N42.6/E-124.1 \\
\hline WLP4 & L. perenne & America, Arizona & $\mathrm{N} 34.1 / \mathrm{E}-110.7$ \\
\hline WLP5 & L. perenne & China, Guangdong & $\mathrm{N} 23.6 / \mathrm{E} 116.8$ \\
\hline WLP6 & L. perenne wild & France & - \\
\hline WLR1 & L. rigidum & France & - \\
\hline WLT1 & L. temulentum var. arvense & France & - \\
\hline WLT2 & L. temulentum var. arvense & China, Guangdong & $\mathrm{N} 23.7 / \mathrm{E} 116.8$ \\
\hline WLT3 & L. temulentum & China, Shanghai & $\mathrm{N} 30.9 / \mathrm{E} 121.8$ \\
\hline WFA1 & F. arundinacea & America, Oregon & N42.3/E-124.1 \\
\hline WFA2 & F. arundinacea & America, Arizona & N34.1/E-110.6 \\
\hline WFA3 & F. arundinacea & Canada, Manitoba & N49.6/E-95.6 \\
\hline WFA4 & F. arundinacea & Canada, Ontario & N49.7/E-94.4 \\
\hline WFAS & F. arundinacea & France & - \\
\hline WFA6 & F. arundinacea & China, Jiangsu & $\mathrm{N} 32.1 / \mathrm{E} 120.4$ \\
\hline WCD1 & Cynodon dactylon & America Arizona & N34.1/E-110.7 \\
\hline
\end{tabular}

Table 2. Primer sequences and annealing temperatures

\begin{tabular}{|c|c|c|c|}
\hline $\begin{array}{l}\text { DNA } \\
\text { region }\end{array}$ & Primer & $\begin{array}{l}\text { Annealing } \\
\text { temperature }\end{array}$ & Sequence $\left(5^{\prime}-3^{\prime}\right)$ \\
\hline$r b d$ & $\begin{array}{l}\text { rbclA-F } \\
\text { rbclA-R }\end{array}$ & $55^{\circ} \mathrm{C}$ & $\begin{array}{l}\text { ATGTCACCACAAACAGAGACTAAAGC } \\
\text { GTYAAATCAAGTCCACCYCG }\end{array}$ \\
\hline $\begin{array}{l}p s b A- \\
\operatorname{tmH} H\end{array}$ & $\begin{array}{l}\mathrm{psbA-F} \\
\mathrm{tmH}-\mathrm{R}\end{array}$ & $60^{\circ} \mathrm{C}$ & $\begin{array}{l}\text { GTTATGCATGAACGTAATGCTC } \\
\text { CGCGCATGGTGGATTCACAATCC }\end{array}$ \\
\hline$I T S 2$ & $\begin{array}{l}\text { S1-F } \\
\text { S2-R }\end{array}$ & $55^{\circ} \mathrm{C}$ & $\begin{array}{l}\text { ATGCGATACTTGGTGTGAAT } \\
\text { GACGCTTCTCCAGACTACAAT }\end{array}$ \\
\hline $\begin{array}{l}\operatorname{atpF}- \\
\operatorname{atpH}\end{array}$ & $\begin{array}{l}\text { atp-F } \\
\text { atp-H }\end{array}$ & $55^{\circ} \mathrm{C}$ & $\begin{array}{l}\text { ACTCGCACACACTCCCTTTCC } \\
\text { GCTTTTATGGAAGCTTTAACAAT }\end{array}$ \\
\hline
\end{tabular}

samples from France were bought from B\&T World Seeds. The species were identified at the Shanghai Entry-Exit Inspection and Quarantine Bureau, Shanghai, China ( $L$. multiflorum, L. perenne and $F$. arundinacea were cultivar, other samples were spontaneous).

\section{$D N A$ extraction, amplification, and sequencing}

Total DNA was extracted from dried seeds using Plant Genomic DNA Kit (DP305-02, Tiangen Biotech, Beijing, China). PCR was performed in $25-\mu \mathrm{L}$ reaction volumes containing approximately $30 \mathrm{ng}$ of genomic DNA, $2 \mu \mathrm{L}$ dNTP (2.5 mM), $1.5 \mathrm{mM} \mathrm{MgCl}, 1 \mu \mathrm{L}$ of each primer, and $0.2 \mu \mathrm{L} \mathrm{Taq}$ DNA polymerase $(5 \mathrm{U} / \mu \mathrm{L}$; Tiangen). The PCR program was as follows: initial denaturation at $94^{\circ} \mathrm{C}$ for $5 \mathrm{~min}$; 35 cycles of 0.5 min at $94^{\circ} \mathrm{C}, 0.5 \mathrm{~min}$ at the annealing temperature shown in
Table 2 , and $0.5 \mathrm{~min}$ at $72^{\circ} \mathrm{C}$; followed by $10 \mathrm{~min}$ at $72{ }^{\circ} \mathrm{C}$, then $4^{\circ} \mathrm{C}$. The primer sequences were selected from CBOL (Table 2 ). PCR products were resolved by $1.5 \%$ agarose gel electrophoresis, purified, and subjected to sequencing (Sangon Biotech, Shanghai, China).

\section{Sequence alignment and phylogenetic analysis}

The DNA sequences were assembled and aligned using the programs ContigExpress (Invitrogen, Carlsbad, CA) and MEGA 5.0 (Tamura et al., 2011). The Kimura 2-parameter (K2P) distances of $r b c L, t r n H-p s b A$, atpF-atpH, and ITS2 were calculated using MEGA 5.0 to evaluate intra-specific and interspecific divergences (Tamura et al., 2011). Based on the K2P model, neighbor joining $(\mathrm{NJ})$ trees were constructed using MEGA 5.0 with Cynodon dactylon as an outgroup. Node support for the NJ tree was inferred with bootstrap analysis (1000 replicates). Species were considered discriminated if all individuals of one species formed a monophyletic group (Hebert et al., 2003). The DNA barcoding gap was calculated by TAXONDNA (Slabbinck et al., 2008).

\section{Results}

\section{PCR amplification and sequencing}

PCR amplification was performed using four pairs of primers, and the results of gel electrophoresis are shown in Fig. 1. Amplifications were successful, and the same results were obtained every time for all primer pairs. Clear individual target bands of about $500 \mathrm{bp}(I T S 2)$ and $600 \mathrm{bp}$ ( $p s b A-t r n H, r b c L$, atpF-atp $H$ ) were consistent with the predicted results. All PCR products of $r b c L$, atpF-atpH, and ITS2 and 93\% of the PCR products of $p s b A-t m H$ could be sequenced successfully (Supplemental data 1-4).

Inter-intraspecific $K 2 P$ distances for four individual DNA barcodes

The pairwise genetic distance values (K2P) calculated using MEGA 5.0 are listed in Table 4. The highest interspecies genetic distance $(0.03)$ was between $L$. perenne and $F$. arundinacea for $p s b$-trn $H$, and the lowest genetic distance (0) was between $L$. perenne and $L$. multiflorum for atpF-atpH. The maximum intraspecific distance for ITS2 was 0.0012 while the minimum intraspecific distance obtained for atp $F$-atp $H$ was 0 . The mean of the inter-specific divergences was significantly higher than those of intra-specific variations in $p s b A$-trnH and ITS2 (Table 3).

Wilcoxon signed rank tests were calculated using SPSS to analyze the interspecific variability of four DNA barcodes (Table 4). The results showed that $p s b A$-trn $H$ and ITS 2 had the highest inter-specific variability, followed by $r b c L$ and atpF-atp $H$. The maximum interspecies distances of ITS 2 and $p s b A$-trnH were greater than the maximum intraspecific distances, in agreement with the requirement for ideal DNA barcodes.

\section{Barcoding gap assessment}

Based on the distribution of inter-intraspecific K2P distances, the barcoding gap and accuracy of each DNA region was assessed (Fig. 2). Intra-interspecific distance overlaps existed in $r b c L$ and $a t p F$-atp $H$, and two distinct barcoding gap existed in each of ITS2 and $p s b A$-trnH between intraspecific and interspecific distances, corresponding to the pairwise genetic 

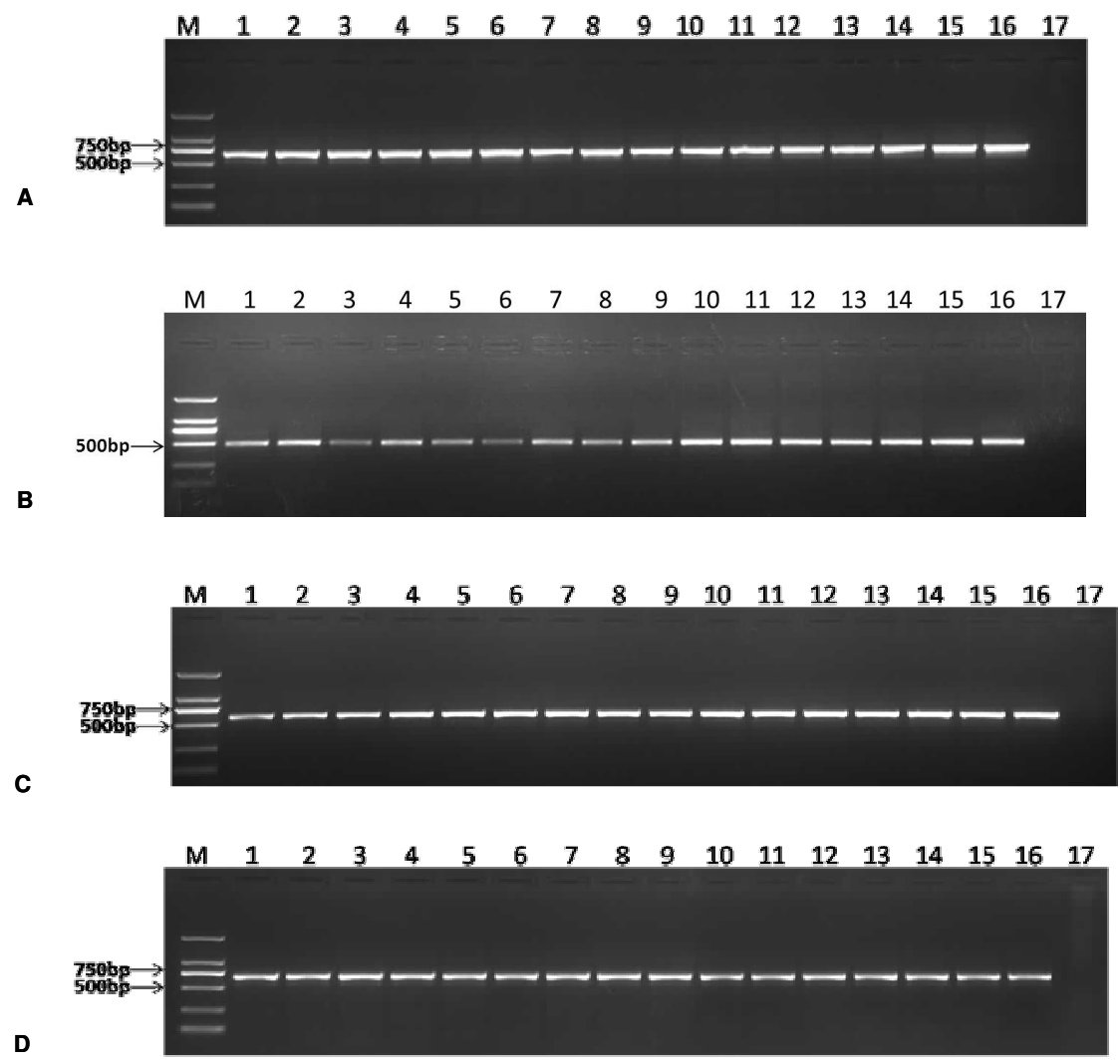

Fig. 1. PCR amplification of $I T S 2$, $p s b A$-trn $H, r b c L$ and atp $F$-atpH regions

M: DM2000 DNA maker, 1-4: Lolium perenne; 5-6: L. multiflorum; 7-8: L. temulentum var. arvense; 9: L. rigidum; 10: L. temulentum; 11-16: Festuca arundinacea; 17: negative control A: psbA-trnH; B: ITS2; C: rbcl; D: atpF-atpH

psbA-trnH

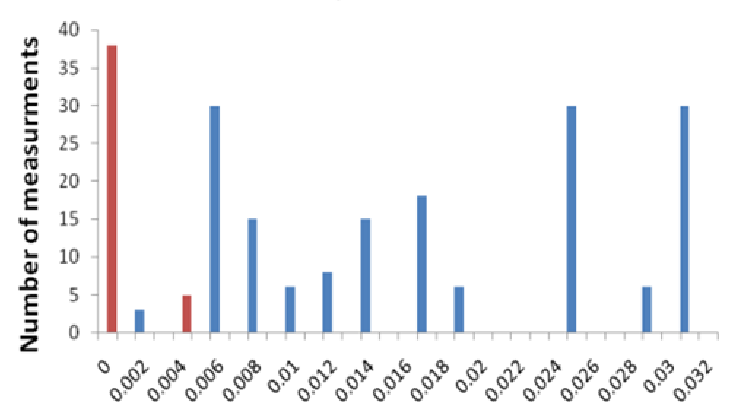

$\mathrm{K} 2 \mathrm{P}$ distance

rbcl

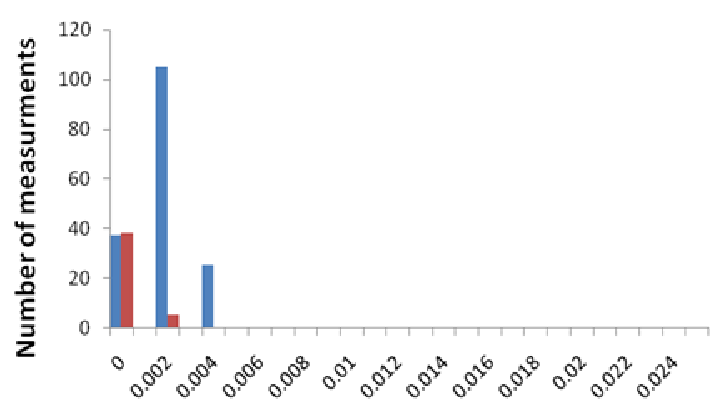

K2P distance
ITS2

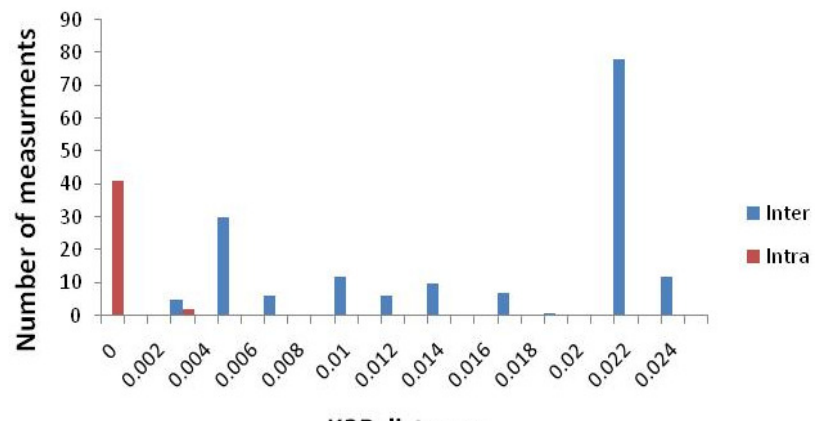

$\mathrm{K} 2 \mathrm{P}$ distance

atpF-atpH

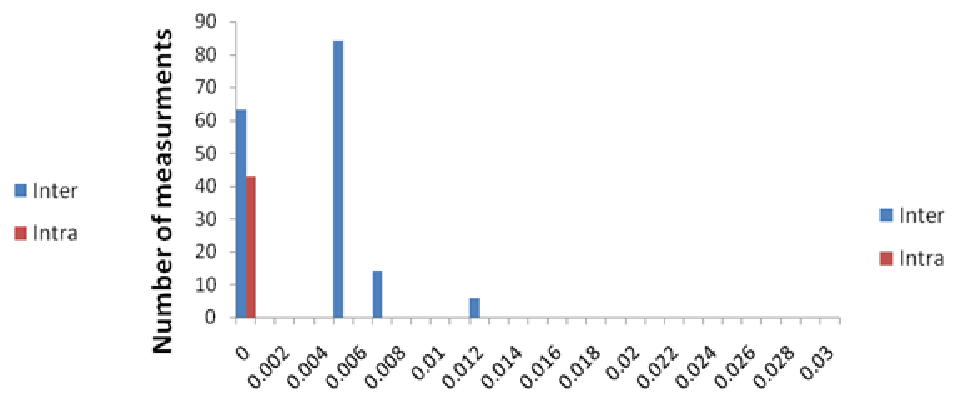

K2P distance

Fig. 2. Relative distributions of DNA barcoding gap between inter and intra-specific K2P distances 
Table 3. The inter-intraspecific K2P distances for four individual DNA barcodes

\begin{tabular}{|c|c|c|c|c|}
\hline Parameters & $p s b A-t m H$ & $r b c l$ & atpF-atpH & ITS2 \\
\hline Number of aligned nucleotide sites & 488 & 564 & 631 & 437 \\
\hline \% amplification success & 100 & 100 & 100 & 100 \\
\hline \% sequencingsuccess & 90 & 100 & 100 & 100 \\
\hline \%Variable nucleotidesites & 16 & 2 & 7 & 14 \\
\hline Lolium multiflorum mean intraspecific distance & 0 & 0 & 0 & 0 \\
\hline Loliumperenne mean intraspecific distance & 0.0012 & 0.0006 & 0 & 0 \\
\hline Lolium rigidum mean intraspecific distance & $\mathrm{n} / \mathrm{c}$ & $\mathrm{n} / \mathrm{c}$ & $\mathrm{n} / \mathrm{c}$ & $\mathrm{n} / \mathrm{c}$ \\
\hline Lolium temulentum mean intraspecific distance & 0 & 0 & 0 & 0.0015 \\
\hline Festuca arundinacea mean intraspecific distance & 0 & 0 & 0 & 0 \\
\hline $\begin{array}{l}\text { Mean interspecific distance between Lolium multiflorum } \\
\text { and Loliumperenne }\end{array}$ & 0.0062 & 0.0033 & 0.0000 & 0.0046 \\
\hline $\begin{array}{l}\text { Mean interspecific distance between Lolium multiflorum } \\
\text { between Lolium rigidum }\end{array}$ & 0.0055 & 0.0018 & 0.0066 & 0.0023 \\
\hline $\begin{array}{l}\text { Mean interspecific distance between Lolium multiflorum } \\
\text { between Lolium temulentum }\end{array}$ & 0.0074 & 0.0018 & 0.0000 & 0.0148 \\
\hline $\begin{array}{l}\text { Mean interspecific distance between Lolium multiflorum } \\
\text { between Festuca arundinacea }\end{array}$ & 0.0243 & 0.0018 & 0.0049 & 0.0211 \\
\hline $\begin{array}{l}\text { Mean interspecific distance between Lolium perenne } \\
\text { between Lolium temulentum }\end{array}$ & 0.0127 & 0.0015 & 0.0000 & 0.0101 \\
\hline $\begin{array}{l}\text { Mean interspecific distance between Loliumperenne } \\
\text { between Lolium rigidum }\end{array}$ & 0.0108 & 0.0015 & 0.0066 & 0.0070 \\
\hline $\begin{array}{l}\text { Mean interspecific distance between Lolium perenne } \\
\text { between Festuca arundinacea }\end{array}$ & 0.0298 & 0.0015 & 0.0049 & 0.0211 \\
\hline $\begin{array}{l}\text { Mean interspecific distance between Lolium rigidum } \\
\text { between Lolium temulentum }\end{array}$ & 0.0018 & 0.0000 & 0.0066 & 0.0171 \\
\hline $\begin{array}{l}\text { Mean interspecific distance between Lolium rigidum } \\
\text { between Festuca arundinacea }\end{array}$ & 0.0187 & 0.0000 & 0.0115 & 0.0235 \\
\hline $\begin{array}{l}\text { Mean interspecific distance between Lolium temulentum } \\
\text { between Festuca arundinacea }\end{array}$ & 0.0168 & 0.0000 & 0.0049 & 0.0219 \\
\hline
\end{tabular}

Table 4. Wilcoxon signed rank test of the inter-specific divergences among the four loci

\begin{tabular}{|c|c|c|c|c|c|}
\hline $\mathrm{W}+$ & W- & & $\mathrm{n}$ & $P$ value & Result \\
\hline$p s b A-\operatorname{trn} H$ & ITS2 & $\begin{array}{l}W+=24.0 \\
W-=31.0\end{array}$ & $\mathrm{n}=10$ & $\mathrm{P} \leq 0.376$ & $p s b A-t r n H=I T S 2$ \\
\hline$p s b A-\operatorname{trn} H$ & $r b c l$ & $\begin{array}{c}W+=55.0 \\
W-=0\end{array}$ & $\mathrm{n}=10$ & $\mathrm{P} \leq 0.001$ & $p s b A-t r n H>r b c l$ \\
\hline$p s b A-\operatorname{trn} H$ & atpF-atpH & $\begin{array}{c}\mathrm{W}+=51.0 \\
\mathrm{~W}-=4.0\end{array}$ & $\mathrm{n}=10$ & $\mathrm{P} \leq 0.002$ & $p s b A-t r n H>a t p F-a t p H$ \\
\hline ITS2 & $r b c l$ & $\begin{array}{c}W+=55.0 \\
W-=0\end{array}$ & $\mathrm{n}=10$ & $\mathrm{P} \leq 0.001$ & ITS $2>r b c l$ \\
\hline ITS2 & atpF-atpH & $\begin{array}{c}\mathrm{W}+=53.0 \\
\mathrm{~W}-=2.0\end{array}$ & $\mathrm{n}=10$ & $\mathrm{P} \leq 0.003$ & IT2 $>$ atp $F-a t p H$ \\
\hline atpF-atpH & $r b c l$ & $\begin{array}{c}\mathrm{W}+=47.0 \\
\mathrm{~W}-=8.0\end{array}$ & $\mathrm{n}=10$ & $\mathrm{P} \leq 0.004$ & atpF-atpH $H>r b c l$ \\
\hline
\end{tabular}

distances.

\section{Species identification based on phylogenetic tree}

The Neighbor Joining trees (Fig. 3) were used to evaluate the ability of these DNA barcodes to identify species. All authenticate species clades were clearly monophyletic and distinct from other clades in the ITS2 and $p s b A$-trn $H$ trees. However, $r b c L$ had $47.6 \%$ resolving ability, and atpF-atpH could not identify any species in Lolium, because there was no genetic variation among individuals. However, the Neighbor Joining trees for ITS2 and $p s b A-t r n H$ did not correctly identify all of the relationships in Lolium and Festuca; for example, the ITS2 and $p s b A$-trn $H$ trees identified different relationships for $L$. temulentum and $F$. arundinacea.

\section{Discussion}

DNA barcoding has been extensively used for species identification and for diversity and ecological studies. In this study, it has been examined four potential DNA barcodes suggested by the CBOL Plant Working Group (2009) and other authors (Kress et al., 2005; Lahaye et al., 2008a). DNA barcodes $r b c L$ and atpF-atp $H$ are universal and easy to amplify. Fazekas et al. (2008) and Newmaster et al. (2008) found that $r b c L$ could not identify all species, but it generally performs quite well in differentiating genera. Sass et al. (2007) obtained similar results. Although atpF-atp $H$ have been used successfully in combination with matK (Lahaye et al., 2008b), the present results revealed that atp $F$-atp $H$ possessed less sequence variation and could not be used for species of Lolium. This finding was in accordance with a previous report by Newmaster et al. (2006), where atpF-atp $H$ did not vary among closely-related species . Thus, these markers should be used only in combination with other barcodes. Several studies have shown $p$ sbA-trn $H$ could be potential barcodes. Kress et al. (2007) used psbA-trnH successfully to discriminate algae, mosses, ferns, gymnosperms, and angiosperms. The current study showed that $p s b A$-trn $H$ was highly variable at the species level, but we encountered severe obstacle in sequencing (perhaps because of a long poly (A) domain), preventing it from being useful in experiment. Chen $e t$ al. (2010) used ITS2 to discriminate more than 6600 plant samples from 480 species in 753 genera with a $92.7 \%$ success rate and Gao et al. (2010) obtained 96.2\% identification success rates at the species level within Fabaceae. In the current study, comparing the five barcode markers in the discrimination of Lolium, ITS 2 was the best option.

Neighbor Joining data of ITS2 indicated that three crosspollinated species: $L$. perenne, $L$.multiflorum, $L$. rigidum and two self-pollinated species: $L$. temulentum, L. temulentum var. arvense grouped together respectively. These findings were in agreement with previous studies (Terrell, 1968; Catalan et al., 1997, 2004; Torrecilla et al., 2004). However, some unusual groupings have occurred in the $\mathrm{NJ}$ dendrogram of $p s b A$-trnH. For example, $L$. temulentum (WLT1-WLT3) and L. rigidum (WLR1) was positioned outside all other Lolium samples, which formed a single clade with $F$. arundinacea. These unusual groupings could be explained by close relationship between two genuses (Charmet et al., 1997).

There are different opinions on relationship of Lolium and Festuca. Some researchers thought that cytological and morphological data do not support separate genera (Stebbins, 1956; Crowder, 1953; Terrell, 1966). Other authors have assumed that Lolium had a common ancestor with Festuca based on its genetic structure (Xu and Sleper, 1994; Torrecilla and Catalan, 2002; Inda et al., 2008). As the present results show, Festuca have shared high homoplasy with Lolium in the $p s b A-\operatorname{trn} H$ region caused by rapid molecular evolution at the loci studied. In the recent studies, Inda (2013) performed a Fluorescent in situ hybridization analysis of genus Lolium based on ribosomal RNA genes, and found that some species could be intermediate between Festuca and Lolium. The current results offered an added data for the taxonomy phylogenetics.

The goals of DNA barcoding have been discussed for a long 
A
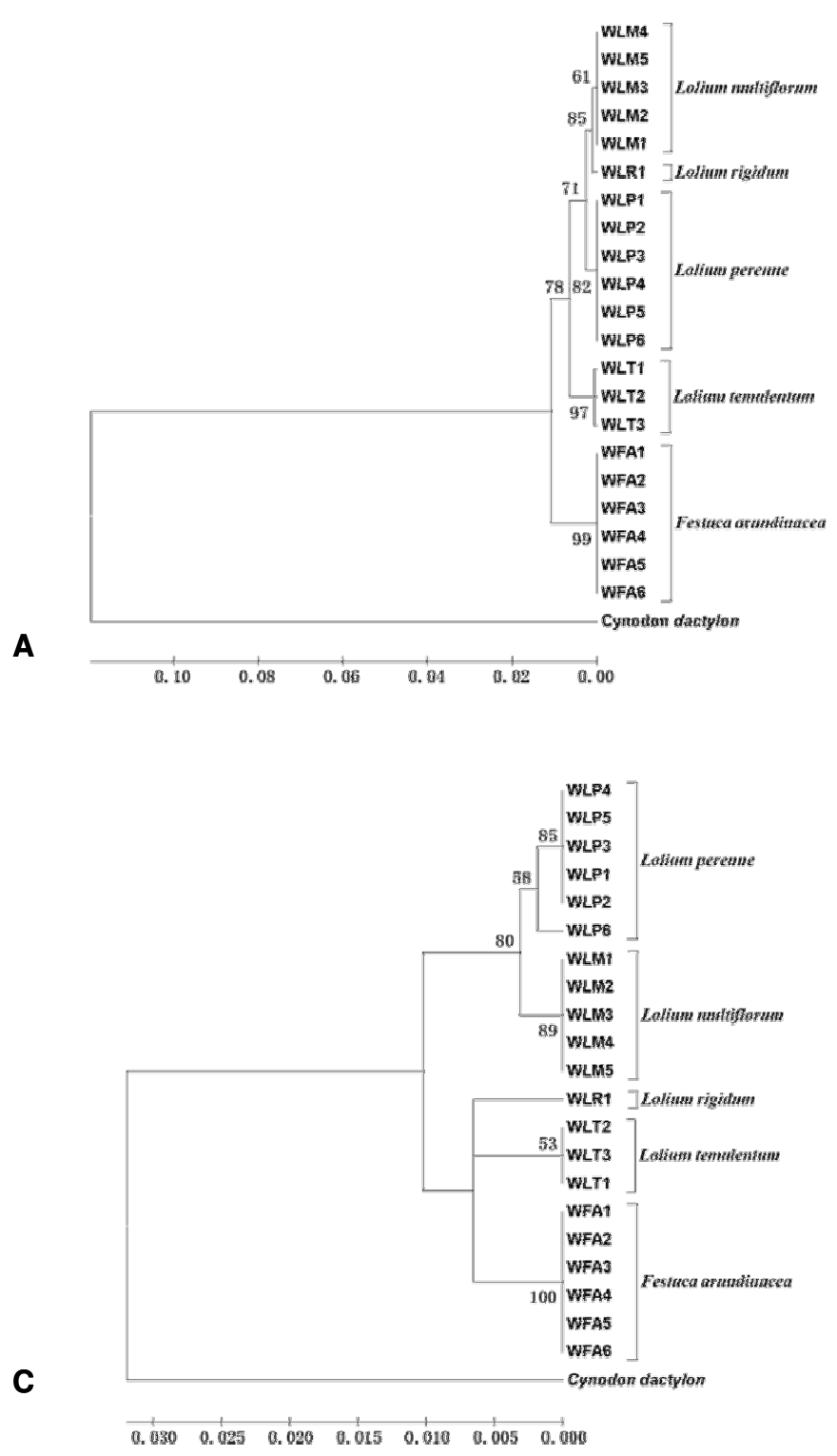
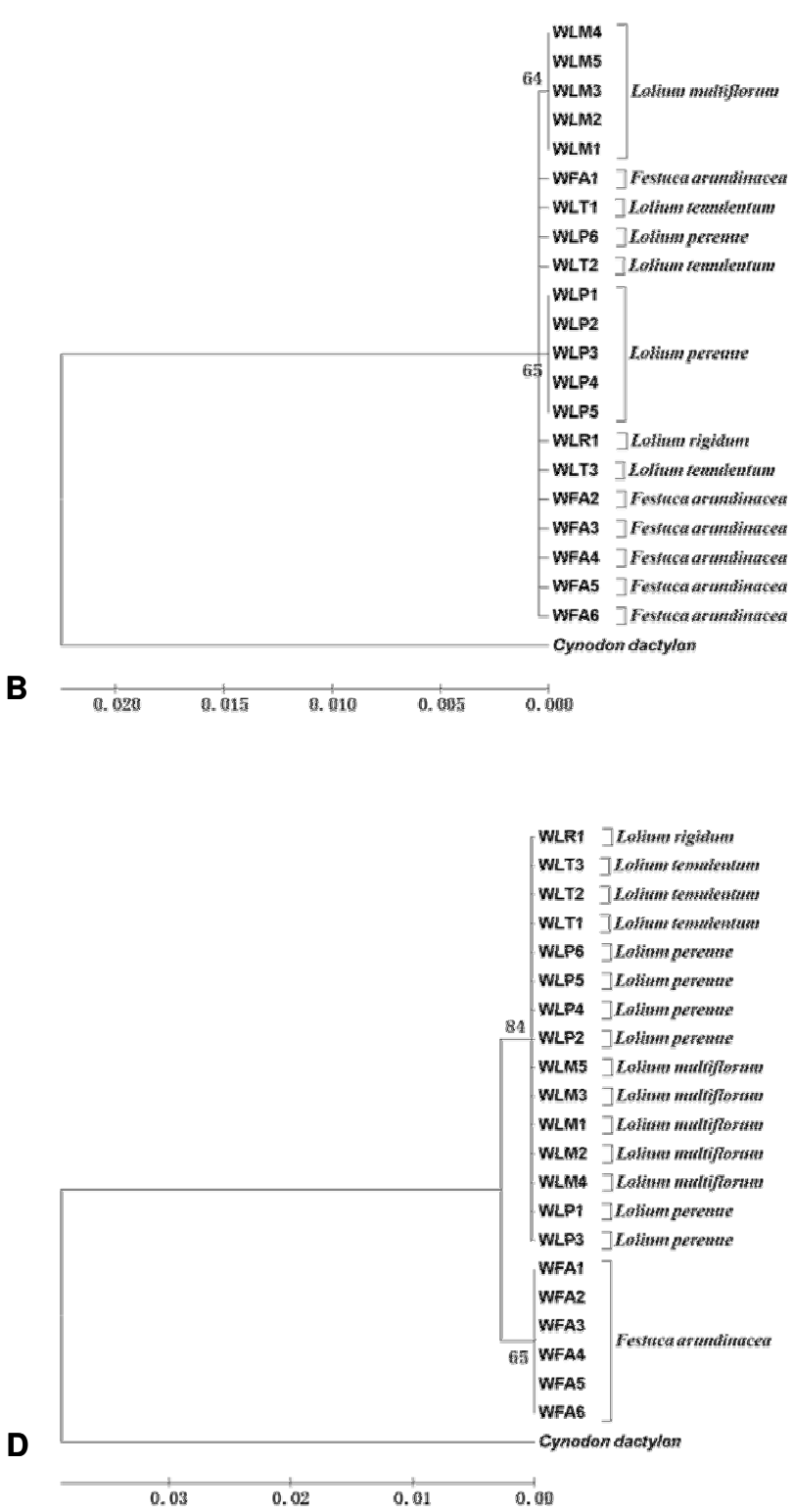

Fig. 3. The Neighbor Joining trees of four DNA barcoding regions. A: ITS2; B: rbcl; C: $p s b A$-trnH; D: atpF-atpH

time; species "discovery" and "identification" are two important and controversial aspects (Desalle, 2006; Hollingsworth, 2011; Zhang et al., 2014; Diana et al., 2012). This method has been extensively applied in animals, but no available DNA barcodes have thus far been able to perfectly identify species in plants (Hollingsworth et al., 2011; China Plant BOL Group, 2011). Although DNA barcodes cannot yet replace traditional taxonomic techniques, its accuracy, richness, and reproducibility will make this digital technology a useful complement for taxonomists and facilitate work on entry-and-exit inspections and quarantine.

\section{Conclusions}

All tested species of Lolium and Festuca were well differentiated and monophyletic using the ITS2 region. The data from $\mathrm{NJ}$ trees provided a new understanding for the origin of two genuses. ITS2 is a reliable DNA barcode for distinguishing genus Lolium.

\section{Acknowledgements}

This work was supported by the National Key Technology R\&D Program of the Ministry of Science and Technology (2012BAK11B03), the National Key Technology Support Program of China (No. 2013BAD12B06) and the project of Food Science Discipline Construction of Shanghai University.

\section{References}

Bhargava M, Sharma A (2013). DNA barcoding in plants: Evolution and applications of in silico approaches and resources. Molecular Phylogenetics and Evolution 67:631-641.

Catalan P, Kellogg EA, Olmstead RG (1997). Phylogeny of Poaceae subfamily Pooideae based on chloroplast $n d h F$ gene sequences. Molecular Phylogenetics and Evolution 8:150-166. 
Catalan P, Torrecilla P, Lopez Rodriguez JA, Olmstead RG (2004). Phylogeny of the Festucoid grasses of subtribe Loliinae and allies (Pooeae, Pooideae) inferred from ITS and trnL-F sequences. Molecular Phylogenetics and Evolution 31:517-541.

Charmet G, Ravel C, Balfourier F (1997). Phylogenetic analysis in the Festuca-Lolium complex using molecular markers and ITS rDNA. Theoretical and Applied Genetics 94(8):1038-1046.

Chen S, Yao H, Han J, Liu C, Song J, Shi L, Leon C (2010). Validation of the ITS 2 region as a novel DNA barcode for identifying medicinal plant species. PLoS ONE 5(1):e8613.

Crowder LV (1953). Interspecific and intergeneric hybrids of Festuca and Lolium. Journal of Heredity 44(5):195-203.

Lopez-Alvarez D, Lopez-Herranz M, Catalan P (2012). A DNA barcoding method to discriminate between the model plant Brachypodium distachyon and its close relatives B. stacei and $B$. bybridum (Poaceae). PLoS ONE 12(7):e51058.

Fazekas AJ, Burgess KS, Kesanakurti PR, Graham SW, Newmaster SG, Husband BC, Barrett SC (2008). Multiple multilocus DNA barcodes from the plastid genome discriminate plant species equally well. PLoS ONE 3(7):e2802.

Gao T, Yao H, Song J, Liu C, Zhu Y, Ma X, Chen S (2010). Identification of medicinal plants in the family Fabaceae using a potential DNA barcode ITS2. Journal of Ethnopharmacology 130(1):116-121.

Hebert PD, Cywinska A, Ball SL (2003). Biological identifications through DNA barcodes. Proceedings of the Royal Society of London Series B: Biological Sciences 270(1512):313-321.

Hollingsworth PM, Graham SW, Little DP (2011). Choosing and using a plant DNA barcode. PLoS ONE 6:e19254.

Hurst E (1942). The Poison Plants of New South Wales. The Snelling Printing Works PTY. LTD, Sidney, Australia pp 15-17.

Inda LA, Segarra-Moragues JG, Müller J, Peterson PM, Catalán P (2008). Dated historical biogeography of the temperate Loliinae (Poaceae, Pooideae) grasses in the northern and southern hemispheres. Molecular Phylogenetics and Evolution 46(3):932957.

Inda LA, Wolny E (2013). Fluorescent in situ hybridization of the ribosomal RNA genes (5S and 35S) in the genus Lolium: Lolium canariense, the missing link with Festuca? In Anales del Jardín Botánico de Madrid 70(1):97-102.

Kitthawee S (2013). ITS2 sequence variations among members of Diachasmim or phalongicaudata complex (Hymenoptera: Braconidae) in Thailand.Journal of Asia-Pacific Entomology 16(2):173-179.

Kress WJ, Erickson DL (2007). A two-locus global DNA barcode for land plants: the coding $r b c L$ gene complements the non-coding trnH-psbA spacer region PLoS ONE 2(6):e508.

Kress WJ, Wurdack KJ, Zimmer EA, Weigt LA, Janzen DH (2005). Use of DNA barcodes to identify flowering plants. Proceedings of the National Academy of Sciences of the United States of America 102(23):8369-8374.
Lahaye R, Savolainen V, Duthoit S, Maurin O, Van der Bank M (2008a). A test of $p s b K-p s b I$ and $a t p F-a t p H$ as potential plant DNA barcodes using the flora of the Kruger National Park as a model system (South Africa). Nature Proceedings 1-21.

Lahaye R, Van der Bank M, Bogarin D, Warner J, Pupulin F, Gigot G, Savolainen V (2008b). DNA barcoding, the floras of biodiversity hotspots. Proceedings of the National Academy of Sciences 105(8):2923-2928.

Liu Z, Zeng X, Yang D, Chu G, Yuan Z, Chen S (2012). Applying DNA barcodes for identification of plant species in the family Araliaceae. Gene 499(1):76-80.

Newmaster SG, Fazekas AJ, Ragupathy S (2006). DNA barcoding in land plants: evaluation of $r b c L$ in a multigene tiered approach. Botany 84(3):335-341.

Newmaster SG, Fazekas AJ, Steeves RAD, Janovec J (2008). Testing candidate plant barcode regions in the Myristicaceae. Molecular Ecology Resources 8(3):480-490.

Raven PH,Zhang L (2013). Flora of China. Science Press.

Sass C, Little DP, Stevenson DW, Specht CD (2007). DNA barcoding in the cycadales: testing the potential of proposed barcoding markers for species identification of cycads. PLoS ONE 2(11):e1154.

Selvaraj D, Shanmughanandhan D, Sarma RK, Joseph JC, Srinivasan RV, Ramalingam S (2012). DNA Barcode ITS Effectively distinguishes the medicinal plant boerhaviadiffusa from its adulterants. Genomics, Proteomics and Bioinformatics 10(6):364 367.

Slabbinck B, Dawyndt P, Martens M, De Vos P, De Baets B (2008). TaxonGap: a visualization tool for intra-and inter-species variation among individual biomarkers. Bioinformatics 24(6):866-867.

Stebbins GL (1956). Taxonomy and evolution of genera with special reference to family Gramineae. Evolution 10:235-245.

Tamura K, Peterson D, Peterson N, Stecher G, Nei M, Kumar S (2011). MEGA5: molecular evolutionary genetics analysis using maximum likelihood, evolutionary distance, and maximum parsimony methods. Molecular Biology and Evolution 28(10):2731-2739.

Terrell EE (1966). Taxonomic implications of genetics in ryegrasses (Lolium). The Botanical Review 32(2):138-164.

Terrell EE (1968) A taxonomic revision of the genus Lolium. Technical Bulletin US Department of Agriculture 1392:1-65.

Torrecilla P, Catalan P (2002). Phylogeny of broad-leaved and fineleaved Festuca lineages (Poaceae) based on nuclear ITS sequences. Systematic Botany 27:241-251.

Torrecilla P, Lopez Rodriguez JA, Catalan P (2004). Phylogenetic relationships of Vulpia and related genera (Poeae, Poaceae) based on analysis of ITS and trnL-F sequences. Annals of the Missouri Botanical Garden 91:124-158.

Xu WW, Sleper DA (1994) Phylogeny of tall fescue and related species using RFLPs. Theoretical and Applied Genetics 88(6-7):685-690.

Zhang D, Duan L, Zhou N (2014). Application of DNA barcoding in Roscoea (Zingiberaceae) and a primary discussion on taxonomic status of Roscoea cautleoides var. pubescens. Biochemical Systematics and Ecology 52:14-19. 